\title{
Effect of Bismuth Oxide on the Microstructure and Electrical Conductivity of Yttria Stabilized Zirconia
}

\author{
Liwei Liu ${ }^{1}$, Zheng Zhou ${ }^{1}$, He Tian ${ }^{2, *}$ and Jixue $\mathrm{Li}^{1, *}$ \\ 1 State Key Laboratory of Silicon Materials, Department of Materials Science and Engineering, Zhejiang \\ University, Hangzhou 310027, China; llwdahai@zju.edu.cn (L.L.); zhouzhengaa@zju.edu.cn (Z.Z.) \\ 2 Center of Electron Microscopy, Zhejiang University, Hangzhou 310027, China \\ * Correspondence: hetian@zju.edu.cn (H.T.); jx_li@zju.edu.cn (J.L.); Tel.: +86-571-8795-2166 (J.L.) \\ Academic Editor: Ki-Hyun Kim \\ Received: 5 January 2016; Accepted: 6 February 2016; Published: 14 March 2016
}

\begin{abstract}
Bismuth oxide $\left(\mathrm{Bi}_{2} \mathrm{O}_{3}\right)$-doped yttria-stabilized zirconia (YSZ) were prepared via the solid state reaction method. $\mathrm{X}$-ray diffraction and electron diffraction spectroscopy results indicate that doping with $2 \mathrm{~mol} \% \mathrm{Bi}_{2} \mathrm{O}_{3}$ and adding $10 \mathrm{~mol} \%$ yttria result in a stable zirconia cubic phase. Adding $\mathrm{Bi}_{2} \mathrm{O}_{3}$ as a dopant increases the density of zirconia to above $96 \%$, while reducing its normal sintering temperature by approximately $250^{\circ} \mathrm{C}$. Moreover, electrical impedance analyses show that adding $\mathrm{Bi}_{2} \mathrm{O}_{3}$ enhances the conductivity of zirconia, improving its capability as a solid electrolyte for intermediate or even lower temperatures.
\end{abstract}

Keywords: solid electrolyte; ionic conductivity; YSZ; bismuth oxide

\section{Introduction}

Because of its good high-temperature electrical conductivity, thermal stability, and chemical stability, $8 \mathrm{~mol} \%$ yttria-stabilized zirconia (8YSZ) ceramic material has been used as an oxygen ion conductor in oxygen sensors [1-4] and solid oxide fuel cells [5-7]. However, the electrical conductivity of this type of material at intermediate temperatures around $600{ }^{\circ} \mathrm{C}$ needs to be improved in order to enhance the stability, sensitivity of electrochemical devices and lower the energy consumption [8-11]. In addition, during the production of $8 \mathrm{YSZ}$, the sintering temperature reaches as high as about $1550{ }^{\circ} \mathrm{C}$, causing manufacturing difficulties. Therefore, it is desirable to reduce the sintering temperature of $8 \mathrm{YSZ}$ as well as increase its conductivity [1,12-14].

Using $\mathrm{Bi}_{2} \mathrm{O}_{3}$ as a sintering aid during sintering can effectively reduce the sintering temperature of zirconia, as well as increase its density. Hirano et al. [15] reported that doping with $1 \mathrm{~mol} \% \mathrm{Bi}_{2} \mathrm{O}_{3}$ decreases the sintering temperature of scandia-stabilized zirconia ceramics by $300{ }^{\circ} \mathrm{C}$, while allowing its electrical conductivity at $1000^{\circ} \mathrm{C}$ and $800^{\circ} \mathrm{C}$ to reach 0.33 and $0.12 \mathrm{~S} / \mathrm{cm}$, respectively. Yeh et al. [12] studied the effect of bismuth doping on YSZ sintering and they discovered that small amounts of $\mathrm{Bi}_{2} \mathrm{O}_{3}$ were able to effectively reduce sintering temperature and promote ceramic densification. Besides serving as a sintering aid, $\mathrm{Bi}_{2} \mathrm{O}_{3}$ is also a very good oxygen ion conductor, and adding $\mathrm{Bi}^{3+}$ to zirconia can also produce oxygen vacancies. Bai et al. [16] studied the effect of $\mathrm{Bi}_{2} \mathrm{O}_{3}$ on the physical and electrochemical properties of scandia-stabilized zirconia, and they found that the conductivity of samples doped with $2 \mathrm{~mol} \% \mathrm{Bi}_{2} \mathrm{O}_{3}$ was also enhanced. Similar results were also discovered by Raghvendra and Prabhakar Singh in $\mathrm{Bi}_{2} \mathrm{O}_{3}$ doped calcia-stabilized zirconia [9] and Sara et al. [17]. Winnubst et al. [18] studied the effects of varying amounts of $\mathrm{Bi}_{2} \mathrm{O}_{3}$ on the ionic conductivity of YSZ, but in those studies it was found that the enhancing effect of $\mathrm{Bi}_{2} \mathrm{O}_{3}$ on the ionic conductivity of YSZ was very limited. Verkerk et al. [19] discovered that due to the emergence of numerous monoclinic phases, $\mathrm{Bi}_{2} \mathrm{O}_{3}$ has a negative influence on the electrical conductivity of YSZ, but they did not study the 
properties of $\mathrm{Bi}_{2} \mathrm{O}_{3}$ doped YSZ in a completely stable cubic phase [12]. Overall the effects which $\mathrm{Bi}_{2} \mathrm{O}_{3}$ can exert on the electrical conductivity of YSZ are not well understood.

In addition, some researchers $[20,21]$ have studied the importance of cation disorder upon aliovalent doping and its effects on the enhancement of ion positional disorder in oxides with fluorite structures like YSZ. It has been previously reported that this positional disorder could result in higher ionic conductivity in solid electrolyte materials. Therefore, we hoped that the addition of $\mathrm{Bi}_{2} \mathrm{O}_{3}$ might also have a influence like that and be beneficial to the improment of the conductivity of YSZ.

This study investigates the influence of $\mathrm{Bi}_{2} \mathrm{O}_{3}$ on the polymorphic phasing and ionic conductivity of YSZ via X-ray diffraction (XRD), electron diffraction, electron microscopy, dielectric spectroscopy, etc. Then we report the effects of bismuth oxide doping on reducing zirconia sintering temperature, increasing the density and conductivity.

\section{Experimental Section}

In this experiment, zirconia powder (99.9\%, Aladdin Industrial Corporation, Shanghai, China) was used as a reactant in the solid state reaction to prepare $\mathrm{Bi}_{2} \mathrm{O}_{3}$ doped YSZ. 8 mol\% YSZ (8YSZ) and $10 \mathrm{~mol} \% \mathrm{YSZ}$ (10YSZ) were each mixed with $2 \mathrm{~mol} \%$ [17,22,23] $\mathrm{Bi}_{2} \mathrm{O}_{3}$ powder $(99.9 \%$, Aladdin Industrial Corporation, Shanghai, China), adding ethanol as an abrasive, and ground in a planetary ball mill for $10 \mathrm{~h}$. The ground powder was then pressed into disks with a diameter of $10 \mathrm{~mm}$ and a thickness of $2 \mathrm{~mm}$ via cold isostatic pressing. The disks were then sintered in air atmosphere for $2 \mathrm{~h}$ at $1100,1200,1300$, and $1400^{\circ} \mathrm{C}$, respectively. An $8 \mathrm{YSZ}$ ceramic disk was sintered at $1550{ }^{\circ} \mathrm{C}$ for $4 \mathrm{~h}$ as a control.

The density of the ceramic disks was determined via the Archimedes method. Crystal structure was studied via X-ray diffraction (X'Pert PRO, PANalytical, Almelo, the Netherlands). Microscopic morphology was characterized with a scanning electron microscope (SEM, SU-70, Hitachi, Tokyo, Japan). Samples for transmission electron microscopy (TEM) and spectroscopy were prepared via a dual beam-focused ion beam (FIB, Quanta 3D FEG, FEI, Hillsboro, OR, USA) instrument. A G2 F20 transmission electron microscope (FEI Tecnai, Hillsboro, OR, USA) was used to perform TEM and high angle annular dark field scanning transmission electron microscopy (HADDF-STEM) analysis on Bi10YSZ samples sintered at $1300^{\circ} \mathrm{C}$. X-ray Energy Dispersive Spectroscopy (EDS) data was acquired at STEM model. For electrodes, the sample disks were first painted with a thin and homogeneous silver slurry lamella as big as the disk surface, and then sintered at $700{ }^{\circ} \mathrm{C}$ for $30 \mathrm{~min}$ to get bright and smooth silver electrodes. The electrical properties of the samples were measured using a VersaSTAT electrochemical workstation (Ametek, Bowen, PA, USA) at $50{ }^{\circ} \mathrm{C}$ intervals from $350{ }^{\circ} \mathrm{C}$ to $650{ }^{\circ} \mathrm{C}$, with the frequency range of $0.1 \mathrm{~Hz}-1 \mathrm{MHz}$ and a voltage of $10 \mathrm{mV}$.

\section{Results and Discussion}

\subsection{Structural Characterization}

Figure 1 is the XRD diffraction pattern of the $2 \mathrm{~mol}^{2} \mathrm{Bi}_{2} \mathrm{O}_{3}$-doped $8 \mathrm{YSZ}$ (2Bi-8YSZ) samples sintered at varying temperatures and $8 \mathrm{YSZ}$ sintered at $1550{ }^{\circ} \mathrm{C}$. Diffraction shows that the primary structure of the sample is cubic phase (c), with small amounts of the monoclinic phase (m). The monoclinic phase exhibits low electrical conductivity and causes material instability due to the polymorphic transitions, thereby making it an undesirable phase for zirconia as a solid electrolyte material. The purpose of the stabilization with yttria is to reduce and eliminate the monoclinic phase in zirconia. Table 1 shows the estimated weight percent of monoclinic phases in different samples for reference. The weight percent of cubic phases is calculated by the internal standard method with the values of RIR and the integrated intensity of the the strongest peak in both phases base on the XRD data. As Figure 1 and Table 1 show, the quantity of monoclinic phase is gradually reduced as the sintering temperature is increased. The 8YSZ sample was in complete cubic phase at the sintering 
temperature of $1550{ }^{\circ} \mathrm{C}$, while the $8 \mathrm{YSZ}$ doped with $2 \mathrm{~mol}^{\circ} \mathrm{Bi}_{2} \mathrm{O}_{3}$ failed to produce a zirconia sample with a complete cubic phase.

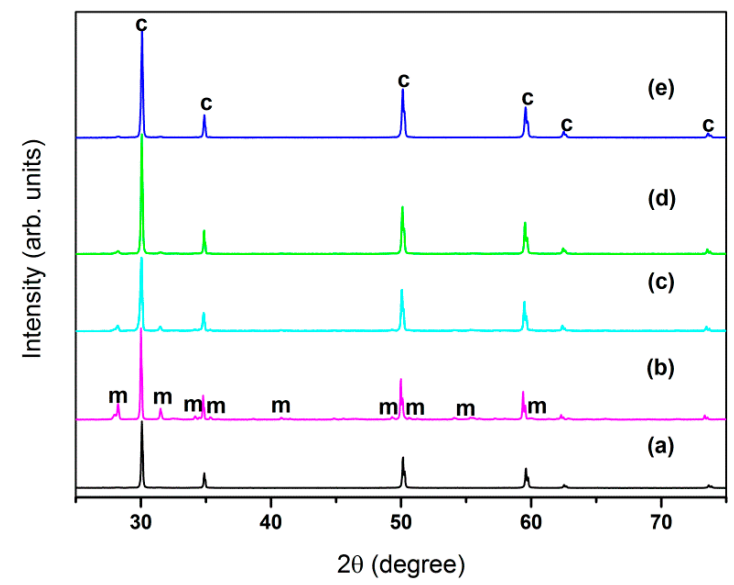

Figure 1. XRD pattern: (a) $8 \mathrm{YSZ} 1550{ }^{\circ} \mathrm{C}$; (b) $2 \mathrm{Bi}-8 \mathrm{YSZ} 1100{ }^{\circ} \mathrm{C}$; (c) $2 \mathrm{Bi}-8 \mathrm{YSZ} 1200^{\circ} \mathrm{C}$; (d) $2 \mathrm{Bi}-8 \mathrm{YSZ}$ $1300^{\circ} \mathrm{C} ;(\mathbf{e}) 2 \mathrm{Bi}-8 \mathrm{YSZ} 1400^{\circ} \mathrm{C}$.

Table 1. The weight percent of monoclinic phases of different samples.

\begin{tabular}{ccc}
\hline Sample & Sintering Temperature $\left({ }^{\circ} \mathbf{C}\right)$ & Weight Percent of Monoclinic Phase (wt $\%)$ \\
\hline 8YSZ & 1550 & 0 \\
2Bi-8YSZ1 & 1100 & 33 \\
2Bi-8YSZ2 & 1200 & 19 \\
2Bi-8YSZ3 & 1300 & 17 \\
2Bi-8YSZ4 & 1400 & 6 \\
2Bi-10YSZ1 & 1100 & 20 \\
2Bi-10YSZ2 & 1200 & 4 \\
2Bi-10YSZ3 & 1300 & 0 \\
2Bi-10YSZ4 & 1400 & 0 \\
\hline
\end{tabular}

Figure 2 is the XRD diffraction pattern of $2 \mathrm{Bi}-10 \mathrm{YSZ}$ sintered at various temperatures and 10YSZ sintered at $1550{ }^{\circ} \mathrm{C}$, and shows that once the sintering temperature exceeds $1300{ }^{\circ} \mathrm{C}, 2 \mathrm{Bi}-10 \mathrm{YSZ}$ no longer contains the monoclinic $\mathrm{ZrO}_{2}$; these results were also verified via selected area electron diffraction analysis.

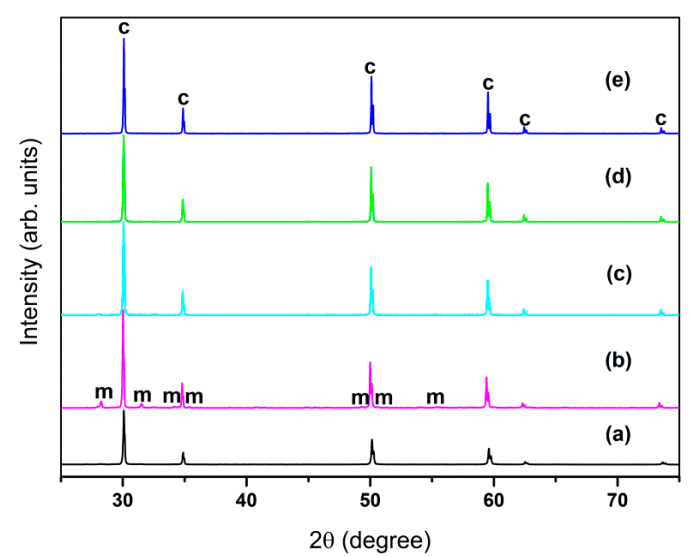

Figure 2. XRD pattern: (a) $10 \mathrm{YSZ} 1550{ }^{\circ} \mathrm{C}$; (b) $2 \mathrm{Bi}-10 \mathrm{YSZ} 1100{ }^{\circ} \mathrm{C}$; (c) $2 \mathrm{Bi}-10 \mathrm{YSZ} 1200^{\circ} \mathrm{C}$; (d) $2 \mathrm{Bi}-10 \mathrm{YSZ}$ $1300^{\circ} \mathrm{C}$; (e) $2 \mathrm{Bi}-10 \mathrm{YSZ} 1400{ }^{\circ} \mathrm{C}$. 


\subsection{Microstructure}

Figure 3 shows scanning electron microscope images of 2Bi-8YSZ sintered at various temperatures. The images indicate that the samples are composed of densely packed grains. Cavity defects decreased with the increased sintering temperatures, and the average grain size increased from about $2.5 \mu \mathrm{m}$ to $13 \mu \mathrm{m}$ as the sintering temperatures increased.



Figure 3. Scanning electron microscope images of $2 \mathrm{Bi}-8 \mathrm{YSZ}$ at various temperatures: (a) $1100{ }^{\circ} \mathrm{C}$; (b) $1200{ }^{\circ} \mathrm{C}$; (c) $1300{ }^{\circ} \mathrm{C}$; (d) $1400{ }^{\circ} \mathrm{C}$.

Figure 4 is a scanning electron micrograph of 2Bi-10YSZ sintered at various temperatures. The image indicates that the $2 \mathrm{Bi}-10 \mathrm{YZ}$ sample has a more uniform morphology as well as fewer small second phase grains. These results are consistent with the XRD analysis results, which all indicate that more yttria $(10 \mathrm{~mol} \%)$ is needed in the system to stabilize zirconia and obtain a uniform, fully stabilized cubic structure. This dense and void-free morphology suggest that adding low-melting $\mathrm{Bi}_{2} \mathrm{O}_{3}$ can significantly improve material density and promote grain growth because of introducing the liquid phase sintering effect $[9,12,18]$. The rounded rather than straight grain boundaries seen in the microstructure can be explained as the results of border infiltration occurring during the liquid sintering process. Table 2 shows the different grain size and density of samples sintered at different temperatures. Doping with $\mathrm{Bi}_{2} \mathrm{O}_{3}$ improved the sample density, and the grain size increased as the sintering temperature increased. Analysis of the XRD spectra and the SEM picture show that 2Bi-10YSZ can form stabilized zirconia with a uniform, dense, and complete cubic phase structure. This type of homogeneous, stable full cubic zirconia will likely exhibit better electrical properties and stability. 


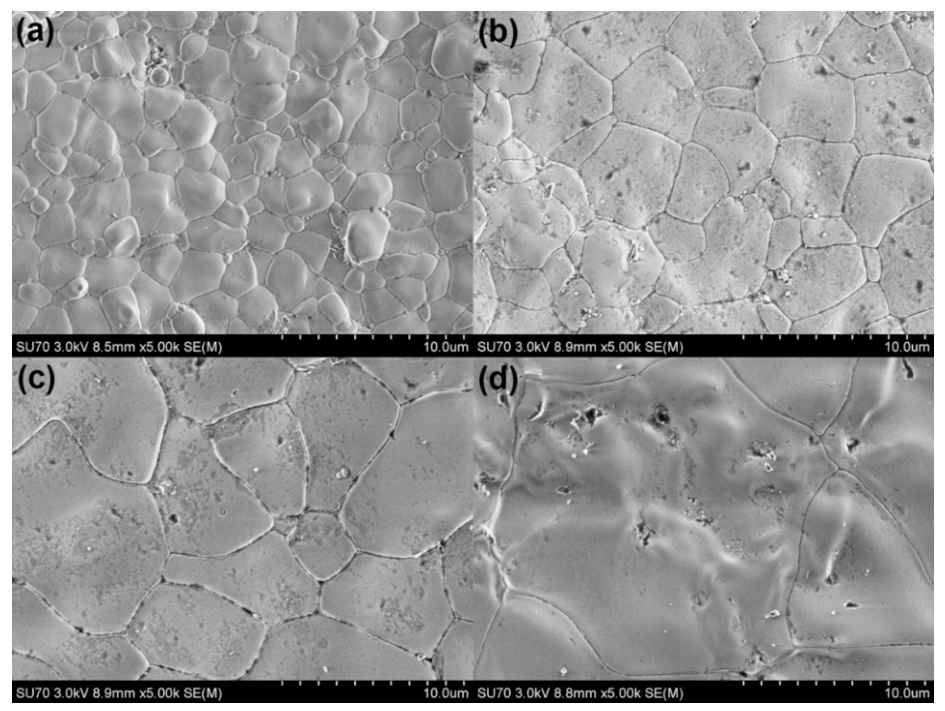

Figure 4. Scanning electron microscope images of $2 \mathrm{Bi}-10 \mathrm{YSZ}$ at various temperatures: (a) $1100{ }^{\circ} \mathrm{C}$; (b) $1200{ }^{\circ} \mathrm{C}$; (c) $1300{ }^{\circ} \mathrm{C}$; (d) $1400{ }^{\circ} \mathrm{C}$.

Table 2. Grain size and densiy of samples.

\begin{tabular}{cccc}
\hline Sample & Sintering Temperature $\left({ }^{\circ} \mathbf{C}\right)$ & Grain Size $(\mu \mathrm{m})$ & Relative Density $(\%)$ \\
\hline 8YSZ & 1550 & 6 & 96.0 \\
2Bi-8YSZ1 & 1100 & 2.5 & 97.5 \\
2Bi-8YSZ2 & 1200 & 5 & 97.8 \\
2Bi-8YSZ3 & 1300 & 10 & 96.7 \\
2Bi-8YSZ4 & 1400 & 13 & 98 \\
2Bi-10YSZ1 & 1100 & 3 & 97.7 \\
2Bi-10YSZ2 & 1200 & 5 & 98.0 \\
2Bi-10YSZ3 & 1300 & 10 & 96.5 \\
2Bi-10YSZ4 & 1400 & 14 & 98.2 \\
\hline
\end{tabular}

\subsection{Transmission Electron Microscopy and EDS Analysis}

As Figure 5a shows, second phase precipitation appeared at triangular grain boundaries and some grain boundaries. $\mathrm{Bi}_{2} \mathrm{O}_{3}$ presented at the grain boundaries can act as fillers in the triangular boundary and increase the material density with the liquid sintering. The high resolution pictures in Figure $5 b, c$ represent the $b$ and $c$ areas marked with rectangles in Figure $5 a$. Figure $5 b$ is a high resolution picture of the grain boundary between two zirconia grains. Figure $5 \mathrm{c}$ is a high resolution picture of the grain boundary between a zirconia and a $\mathrm{Bi}_{2} \mathrm{O}_{3}$ grain. The high resolution pictures show that there are only 2-3 atomic layers at the transition interphase between the zirconia grain boundaries, while the transition interphase is slightly widened between the zirconia and $\mathrm{Bi}_{2} \mathrm{O}_{3}$ grains. There was no amorphous layer in both grain boundaries. The impurities present in an amorphous layer are high resistance materials, which will block the conduction and migration of oxygen vacancies. Thus, the lack of an amorphous layer at the grain boundary can also enhance conductivity. As Figure $5 \mathrm{c}$ shows, the zirconia and $\mathrm{Bi}_{2} \mathrm{O}_{3}$ grains contact and converge nicely at the grain boundary, which makes the $\mathrm{Bi}_{2} \mathrm{O}_{3}$ located in the boundary looks like a bridge linking the zirconia grains together.

Figure 6 is a selected area electron diffraction pattern of $2 \mathrm{Bi}-10 \mathrm{YSZ}$ sample sintered at $1300^{\circ} \mathrm{C}$. The diffraction zone axis in Figure 6a,b are the [011] and [001] cubic directions. SAED results confirm that the crystal configuration of $2 \mathrm{Bi}-10 \mathrm{YSZ}$ is the cubic phase structure. The spectrum shown in Figure $7 \mathrm{~b}$ is the analysis result of the " $b$ " area in Figure $7 \mathrm{a}$, in which a bismuth peak also proves that some $\mathrm{Bi}_{2} \mathrm{O}_{3}$ is dissolved in the zirconia lattice, that is, $\mathrm{Bi}_{2} \mathrm{O}_{3}$ and yttria have a co-doping effect in the zirconia lattice. EDS spectrum analysis (Figure 7a,c) show that oxygen, yttria, and zirconium are uniformly distributed 
in the material without significant segregation, while bismuth segregation is mainly observed at the triangular grain boundary. Transmission electron microscopy and EDS analysis demonstrate that $\mathrm{Bi}_{2} \mathrm{O}_{3}$ is present in grains and grain boundaries, and enhances the density and conductivity of the material.



Figure 5. 2Bi-10YSZ sample sintered at $1300^{\circ} \mathrm{C}$ : (a) HADDF-STEM image; $(\mathbf{b}, \mathbf{c})$ high-resolution images of grain boundaries.

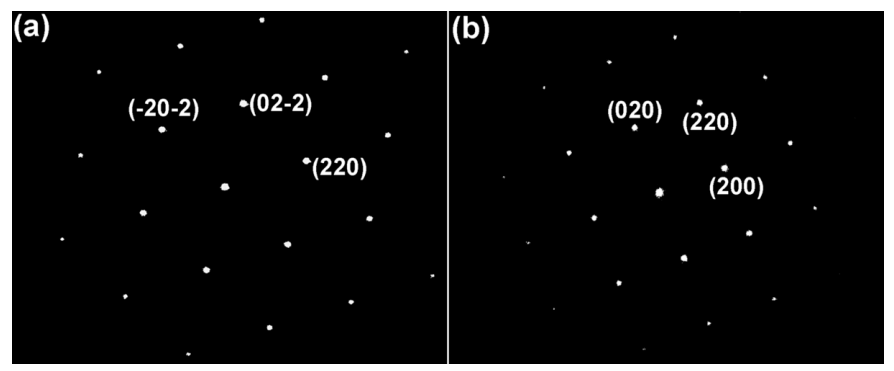

Figure 6. Selected area electron diffraction pattern of 2Bi-10YSZ sampled sintered at $1300{ }^{\circ} \mathrm{C}$ : (a) FCC zone axis [011]; (b) FCC zone axis [001].



Figure 7. (a) HADDF-STEM image of 2Bi-10YSZ; (b,c) EDS energy spectrum. 


\subsection{Impedance and Conductivity Measurement and Analysis}

Figure 8 is a complex impedance plane plot, or Nyquist plot, of 8 YSZ and 2Bi-10YSZ samples of different sintering temperatures tested at $500{ }^{\circ} \mathrm{C}$. The data processing methods for all samples are the same; deduction correction was performed on the curves with the ohmic resistance contribution to allow a better comparation for the resistances of different samples. All impedance data was processed and analyzed using ZSimpWin software. The lines in Figure 8 are the experiment data and the different symbols with different colors are the fitting results. Grain or grain boundary resistance is calculated by fitting two series RQ circuit elements to the impedance spectra. The derived equivalent circuit diagram of the impedance curve is shown in the insert of Figure 8. The high frequency and low frequency semicircle of 2Bi-10YSZ sample shown in Figure 8 represent the grain resistance and grain boundary resistance $[17,24,25]$, respectively. Due to the relaxation properties of different materials and the relatively high measurement temperature, the high-frequency semicircle of the 8YSZ sample represents its grain boundary resistance, and the grain resistance is calculated via the horizontal intercept of the high frequency impedance curve [16,25]. As for the capacitance (C), it can be calculated with the data of the constant phase element $(\mathrm{Q})$. The valves of $\mathrm{C}$ are of the expected magnitude, i.e., of about $10^{-10} \mathrm{~F}$ and $10^{-7} \mathrm{~F}$ for the grains and the grain boundaries, respectively.

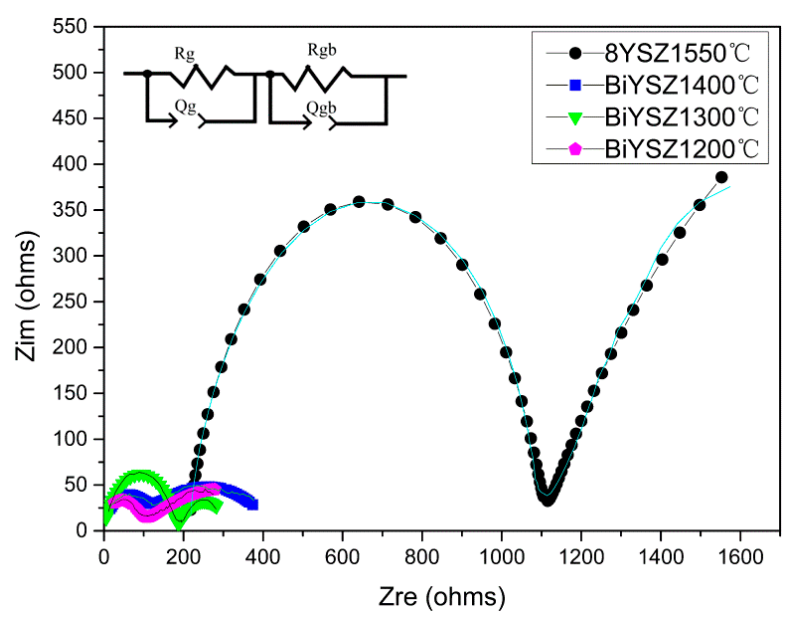

Figure 8. Nyquist plot of $8 \mathrm{YSZ}$ sintered at $1550^{\circ} \mathrm{C}$ and $2 \mathrm{Bi}-10 \mathrm{YSZ}$ sintered at various temperatures.

The figure shows that compared with the 8YSZ sample, which has almost the highest electrical conductivity among all YSZ materials $[3,5,26]$, the 2Bi-10YSZ samples have decreased high and low frequency semicircles. In the 8YSZ sample, the bulk resistance mainly comes from the grain boundary resistance; while in 2Bi-10YSZ sample, the grain boundary resistance is close to the grain resistance. The grain boundary resistance significantly decreased in 2Bi-10YSZ, while its grain resistance also slightly decreased, indicating an improvement of the electrical properties. Similar phenomena have been reported by Raghvendra and Prabhakar Singh [9] in $\mathrm{Bi}_{2} \mathrm{O}_{3}$ doped calcium oxide stabilized zirconia materials; and it has also been discovered by Bai et al. [16] in $\mathrm{Bi}_{2} \mathrm{O}_{3}$-doped scandia stabilized zirconia.

Comparison between 2Bi-10YSZ samples of different sintering temperatures shows that the sample sintered at $1300{ }^{\circ} \mathrm{C}$ exhibits the lowest total resistance. Figure 9 is an Arrhenius curve of $2 \mathrm{Bi}-10 \mathrm{YSZ}$ sintered at $1300{ }^{\circ} \mathrm{C}$ and $8 \mathrm{YSZ}$ sintered at $1550{ }^{\circ} \mathrm{C}$ showing the ionic conductivity plotted against inverse temperature. The sample conductivity is calculated as: $\sigma=\frac{L}{R A}$. $\mathrm{L}$ and $A$ are the thickness and circular area of the test wafer sample, respectively, and $R$ is the resistance of grain or grain boundaries. In 2Bi-10YSZ samples, the sample sintered at $1300{ }^{\circ} \mathrm{C}$ exhibits the highest conductivity of $0.013 \mathrm{~S} / \mathrm{cm}$ at $650{ }^{\circ} \mathrm{C}$, and the conductivity of $8 Y S Z$ sintered at $1550{ }^{\circ} \mathrm{C}$ is about $0.003 \mathrm{~S} / \mathrm{cm}$ at $650{ }^{\circ} \mathrm{C}$, demonstrating that adding $\mathrm{Bi}_{2} \mathrm{O}_{3}$ improves the conductivity to about four times the original conductivity. 


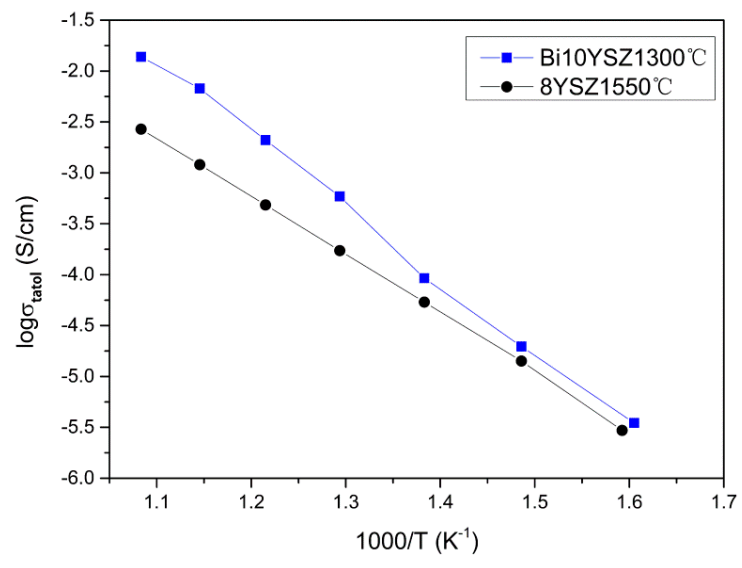

Figure 9. Arrhenius curve of $8 \mathrm{YSZ}$ sintered at $1550{ }^{\circ} \mathrm{C}$ and $2 \mathrm{Bi}-10 \mathrm{YSZ}$ sintered at $1300^{\circ} \mathrm{C}$.

In Figure 10, the grain and grain boundary Arrhenius curves of $8 \mathrm{YSZ}$ of $1550^{\circ} \mathrm{C}$ and $2 \mathrm{Bi}-10 \mathrm{YSZ}$ of $1300{ }^{\circ} \mathrm{C}$ show that the improvement of sample conductivity of 2Bi-10YSZ mainly occurs in the grain boundaries. When the test temperature is higher than $500{ }^{\circ} \mathrm{C}$, the grain conductivity of Bi10YSZ is also higher than that of $8 \mathrm{YSZ}$. One of the reasons for the conductivity improvement is the promotion of grain growth by $\mathrm{Bi}_{2} \mathrm{O}_{3}$, affording a high density material. Another important reason for the boundary improvement is attributed to the aggregation and segregation of some $\mathrm{Bi}_{2} \mathrm{O}_{3}$. Bismuth oxide-based electrolyte is a widely used solid electrolyte material, which has a higher ionic conductivity than zirconia-based materials. Because these materials contain more oxygen vacancies on one side. On the other side, $\mathrm{Bi}^{3+}$ has a high polarization capability due to the influence of $6 \mathrm{~s}^{2}$ lone pair electrons and a strong ability to adapt and integrate to a relatively disordered surroundings [27-29]. Thus, $\mathrm{Bi}_{2} \mathrm{O}_{3}$ segregated at the grain boundaries can remove impurities, such as aluminum oxide, silicon oxide, etc. [30,31], so that the amorphous phase with high resistance is absent at the grain boundaries. What's more, the $\mathrm{Bi}_{2} \mathrm{O}_{3}$ segregated at grain boundaries bridges the grains for oxygen transportation and increases the sample conductivity. And for the part of grain conductivity, the $\mathrm{Bi}_{2} \mathrm{O}_{3}$ infiltrated into the zirconia grains can also generate oxygen vacancies due to the charge compensation mechanism, of which the defect reaction can be represented by the following equation: $\mathrm{Bi}_{2} \mathrm{O}_{3} \stackrel{\mathrm{ZrO}_{2}}{\rightarrow} 2 \mathrm{Bi}_{\mathrm{Zr}}^{\prime}+3 \mathrm{O}_{\mathrm{O}}^{\mathrm{X}}+\ddot{V}_{\mathrm{O}}$.

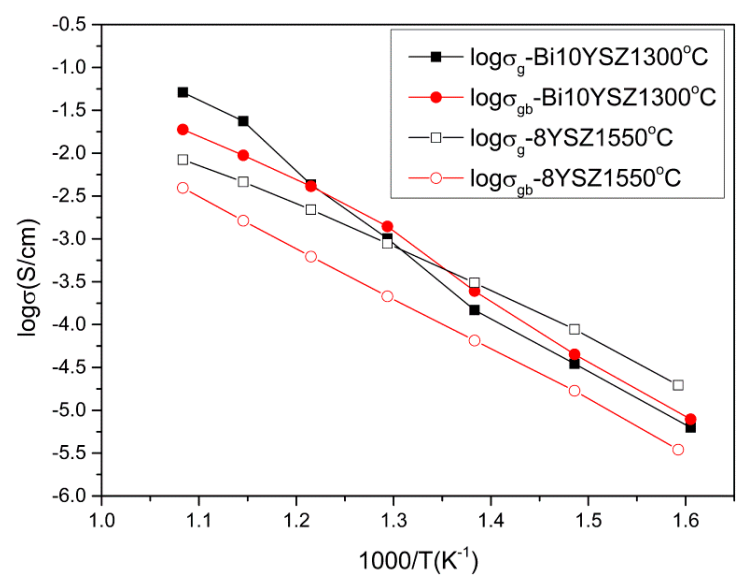

Figure 10. Grain and grain boundary Arrhenius curve of $8 \mathrm{YSZ}$ sintered at $1550{ }^{\circ} \mathrm{C}$ and $2 \mathrm{Bi}-10 \mathrm{YSZ}$ sintered at $1300{ }^{\circ} \mathrm{C}$.

However, at low temperatures, these oxygen vacancies cannot migrate freely, and most of which will bind and interact with cations. Thus, at lower temperatures, the 2Bi-10YSZ grain conductivity has no big difference with that of 8YSZ. When the temperature becomes higher, more vacancies get free 
from association to migrate. The conductivity of the 2Bi-10YSZ grain increases notably in the latter range and the grain conductivity of 2Bi-10YSZ also become higher than that of $8 \mathrm{YSZ}$. Table 3 shows the activation energies for grain and grain boundary of 8 YSZ and Bi10YSZ. They are sintered at $1550{ }^{\circ} \mathrm{C}$ and $1300{ }^{\circ} \mathrm{C}$ separately. All the activation energies are similar to the published data [7,32]. It indicates that when $\mathrm{Bi}_{2} \mathrm{O}_{3}$ is added in $\mathrm{YSZ}$, the activation energies increase. The increace may be ascribed to the added oxygen vacancies with more correlation effects and the lattice distortion in both the grain and grain boundary caused by the solution of $\mathrm{Bi}_{2} \mathrm{O}_{3}$ in the grain and the segregation of $\mathrm{Bi}_{2} \mathrm{O}_{3}$ in the grain boundary, respectively. Thus, there are more vacancies and defect positions in the Bi10YSZ, which is benificial to the ions transport and then the conductivity of the sample becomes more sensitive to the temperature.

Table 3. Activation energies of grain and grain boundary of 8YSZ and Bi10YSZ.

\begin{tabular}{ccc}
\hline Sample & Activation Energy of Grain (eV) & Activation Energy of Grain Boundary (eV) \\
\hline $8 \mathrm{YSZ}-1550^{\circ} \mathrm{C}$ & 1.03 & 1.17 \\
Bi10YSZ-1300 ${ }^{\circ} \mathrm{C}$ & 1.35 & 1.26 \\
\hline
\end{tabular}

\section{Conclusions}

Doping with $\mathrm{Bi}_{2} \mathrm{O}_{3}$ enhances the grain growth of 10YSZ, reduces its sintering temperature and improves its ionic conductivity. $10 \mathrm{~mol} \% \mathrm{YSZ}$ doped with $2 \mathrm{~mol} \% \mathrm{Bi}_{2} \mathrm{O}_{3}$ exists in a completely stable cubic phase after sintering at $1300{ }^{\circ} \mathrm{C}$. Due to the filling effect of $\mathrm{Bi}_{2} \mathrm{O}_{3}$ at grain boundaries, $2 \mathrm{Bi}-10 \mathrm{YSZ}$ has a higher conductivity of $0.013 \mathrm{~S} / \mathrm{cm}$ at $650^{\circ} \mathrm{C}$, which is about four times higher than that of $8 \mathrm{YSZ}$.

Acknowledgments: This work was financially supported by the National Natural Science Foundation of China (grant No. 11227403) and Cyrus Tang Center for Sensor Materials and Applications.

Author Contributions: Liwei Liu and Jixue Li conceived and designed the experiments; Liwei Liu and Zheng Zhou performed the experiments; Jixue Li, Liwei Liu and He Tian analyzed the data; Zheng Zhou contributed analysis tools; Jixue Li and Liwei Liu wrote the paper.

Conflicts of Interest: The authors declare no conflict of interest.

\section{References}

1. Lee, J.-H. Review on zirconia air-fuel ratio sensors for automotive applications. J. Mater. Sci. 2003, 38, 4247-4257. [CrossRef]

2. Goodenough, J.B. Oxide-Ion Electrolytes. Annu. Rev. Mater. Res. 2003, 33, 91-128. [CrossRef]

3. Haering, C.; Roosen, A.; Schichl, H. Degradation of the electrical conductivity in stabilised zirconia systems: Part I: Yttria-stabilised zirconia. Solid State Ion. 2005, 176, 253-259. [CrossRef]

4. Maskell, W.C. Progress in the development of zirconia gas sensors. Solid State Ion. 2000, 134, 43-50. [CrossRef]

5. Fergus, J.W. Electrolytes for solid oxide fuel cells. J. Power Sources 2006, 162, 30-40. [CrossRef]

6. Steele, B.C.H.; Heinzel, A. Materials for fuel-cell technologies. Nature 2001, 414, 345-352. [CrossRef] [PubMed]

7. Shao, Z.; Zhou, W.; Zhu, Z. Advanced synthesis of materials for intermediate-temperature solid oxide fuel cells. Prog. Mater. Sci. 2012, 57, 804-874. [CrossRef]

8. Wachsman, E.D.; Lee, K.T. Lowering the Temperature of Solid Oxide Fuel Cells. Science 2011, 334, $935-939$. [CrossRef] [PubMed]

9. Singh, P. Influence of $\mathrm{Bi}_{2} \mathrm{O}_{3}$ additive on the electrical conductivity of calcia stabilized zirconia solid electrolyte. J. Eur. Ceram. Soc. 2015, 35, 1485-1493.

10. Fergus, J.W. Doping and defect association in oxides for use in oxygen sensors. J. Mater. Sci. 2003, 38, 4259-4270. [CrossRef]

11. Ramamoorthy, R.; Dutta, P.K.; Akbar, S.A. Oxygen sensors: Materials, methods, designs and applications. J. Mater. Sci. 2003, 38, 4271-4282. [CrossRef]

12. Yeh, T.H.; Kusuma, G.E.; Suresh, M.B.; Chou, C.C. Effect of sintering process on the microstructures of $\mathrm{Bi}_{2} \mathrm{O}_{3}$-doped yttria stabilized zirconia. Mater. Res. Bull. 2010, 45, 318-323. [CrossRef] 
13. Hbaieb, K. Reducing sintering temperature of yttria stabilized zirconia through addition of lithium nitrate and alumina. Ceram. Int. 2012, 38, 4159-4164. [CrossRef]

14. Maskell, W.C.; Brett, D.J.L.; Brandon, N.P. Thick-film amperometric zirconia oxygen sensors: Influence of cobalt oxide as a sintering aid. Meas. Sci. Technol. 2014, 25, 065104. [CrossRef]

15. Hirano, M.; Oda, T.; Ukai, K.; Mizutani, Y. Effect of $\mathrm{Bi}_{2} \mathrm{O}_{3}$ additives in Sc stabilized zirconia electrolyte on a stability of crystal phase and electrolyte properties. Solid State Ion. 2003, 158, 215-223. [CrossRef]

16. Bai, B.; Sammes, N.M.; Smirnova, A.L. Physical and electrochemical characterization of $\mathrm{Bi}_{2} \mathrm{O}_{3}$-doped scandia stabilized zirconia. J. Power Sources 2008, 176, 76-81. [CrossRef]

17. Sarat, S.; Sammes, N.; Smirnova, A. Bismuth oxide doped scandia-stabilized zirconia electrolyte for the intermediate temperature solid oxide fuel cells. J. Power Sources 2006, 160, 892-896. [CrossRef]

18. Winnubst, A.J.A.; Burggraaf, A.J. Preparation and electrical properties of a monophasic $\mathrm{ZrO}_{2}-\mathrm{Y}_{2} \mathrm{O}_{3}-\mathrm{Bi}_{2} \mathrm{O}_{3}$ solid electrolyte. Mater. Res. Bull. 1984, 19, 613-619. [CrossRef]

19. Verkerk, M.J.; Winnubst, A.J.A.; Burggraaf, A.J. Effect of impurities on sintering and conductivity of yttria-stabilized zirconia. J. Mater. Sci. 1982, 17, 3113-3122. [CrossRef]

20. Garcia-Barriocanal, J.; Rivera-Calzada, A.; Varela, M.; Sefrioui, Z.; Díaz-Guillén, M.R.; Moreno, K.J.; Díaz-Guillén, J.A.; Iborra, E.; Fuentes, A.F.; Pennycook, S.J.; et al. Tailoring Disorder and Dimensionality: Strategies for Improved Solid Oxide Fuel Cell Electrolytes. ChemPhysChem 2009, 10, 1003-1011. [CrossRef] [PubMed]

21. León, C.; Lucía, M.L.; Santamaría, J.; Sánchez-Quesada, F. Universal scaling of the conductivity relaxation in crystalline ionic conductors. Phys. Rev. B 1998, 57, 41-44. [CrossRef]

22. Flegler, A.J.; Burye, T.E.; Yang, Q.; Nicholas, J.D. Cubic yttria stabilized zirconia sintering additive impacts: A comparative study. Ceram. Int. 2014, 40, 16323-16335. [CrossRef]

23. Liu, M.; He, C.; Wang, J.; Wang, W.G.; Wang, Z. Investigation of $\left(\mathrm{CeO}_{2}\right)_{\mathbf{x}}\left(\mathrm{Sc}_{2} \mathrm{O}_{3}\right)_{(0.11-x)}\left(\mathrm{ZrO}_{2}\right)_{0.89}$ $(\mathrm{x}=0.01-0.10)$ electrolyte materials for intermediate-temperature solid oxide fuel cell. J. Alloys Compd. 2010, 502, 319-323. [CrossRef]

24. Khare, J.; Joshi, M.P.; Satapathy, S.; Srivastava, H.; Kukreja, L.M. Impedance spectroscopy of pellets made from yttria stabilized zirconia nanoparticles generated via $\mathrm{CW}$ and pulsed mode of laser vaporization method. Ceram. Int. 2014, 40, 14677-14685. [CrossRef]

25. Angle, J.P.; Steppan, J.J.; Thompson, P.M.; Mecartney, M.L. Parameters influencing thermal shock resistance and ionic conductivity of $8 \mathrm{~mol} \%$ yttria-stabilized zirconia (8YSZ) with dispersed second phases of alumina or mullite. J. Eur. Ceram. Soc. 2014, 34, 4327-4336. [CrossRef]

26. Vijay, S.K.; Chandramouli, V.; Khan, S.; Clinsha, P.C.; Anthonysamy, S. Microwave assisted gel-combustion synthesis of $8 \mathrm{~mol} \%$ YSZ: A study of the effect of fuel on the ionic conductivity. Ceram. Int. 2014, 40, 16689-16699. [CrossRef]

27. Sammes, N.M.; Tompsett, G.A.; Näfe, H.; Aldinger, F. Bismuth based oxide electrolytes—Structure and ionic conductivity. J. Eur. Ceram. Soc. 1999, 19, 1801-1826. [CrossRef]

28. Lee, K.T.; Lidie, A.A.; Jeon, S.Y.; Hitz, G.T.; Song, S.J.; Wachsman, E.D. Highly functional nano-scale stabilized bismuth oxides via reverse strike co-precipitation for solid oxide fuel cells. J. Mater. Chem. A 2013, 1, 6199-6207. [CrossRef]

29. Wang, S.-F.; Hsu, Y.-F.; Tsai, W.-C.; Lu, H.-C. The phase stability and electrical conductivity of $\mathrm{Bi}_{2} \mathrm{O}_{3}$ ceramics stabilized by Co-dopants. J. Power Sources 2012, 218, 106-112. [CrossRef]

30. Guo, X. Roles of Alumina in Zirconia for Functional Applications. J. Am. Ceram. Soc. 2003, 86, 1867-1873. [CrossRef]

31. Yoon, S.; van Tyne, C.J.; Lee, H. Effect of alumina addition on the microstructure and grain boundary resistance of magnesia partially-stabilized zirconia. Curr. Appl. Phys. 2014, 14, 922-927. [CrossRef]

32. Guo, X.; Sigle, W.; Maier, J. Blocking Grain Boundaries in Yttria-Doped and Undoped Ceria Ceramics of High Purity. J. Am. Ceram. Soc. 2003, 86, 77-87. [CrossRef]

(C) 2016 by the authors; licensee MDPI, Basel, Switzerland. This article is an open access article distributed under the terms and conditions of the Creative Commons by Attribution (CC-BY) license (http://creativecommons.org/licenses/by/4.0/). 